\title{
Penerapan Model Pembelajaran Numbered Heads Together Dalam Meningkatkan Aktivitas Dan Hasil Belajar Siswa Pokok Bahasan Matriks Siswa Kelas XI IPS 2 SMA Negeri 1 Wera Bima
}

\author{
Dusalan*1 $^{1}$, Saifullah ${ }^{2}$ \\ ${ }^{1}$ Program Studi Pendidikan Matematika, STKIP Bima \\ Email: dusalanbima84@gmail.com
}

\section{ABSTRAK}

Tujuan Penelitian ini adalah untuk meningkatkan aktivitas dan hasil belajar siswa pada materi matriks kelas XI IPS 2 SMAN 1 Wera Tahun Pelajaran 2019/2020 melalui penerapan model Number Heards Together. Jenis penelitian ini adalah Penelitian Tindakan Kelas (PTK). Penelitian ini dilaksanakan dua siklus yang memuat tahap perencanaan, pelaksanaan, observasi dan refleksi. Instrumen penelitian ini menggunakan: (1) Rencana Pelaksanaan Pembelajaran (2) tes evaluasi hasil belajar yang diberikan pada tiap siklus kegiatan belajar mengajar (3) lembar observasi yang digunakan untuk memperoleh gambaran langsung tentang aktivitas belajar guru dan siswa melalui penerapan Numbered Heards Together.

Dari hasil penelitian dapat ditarik kesimpulan bahwa penerapan model Number Heards Together dapat meningkatkan belajar matematika siswa, hal ini ditunjukkan oleh rata-rata skor aktivitas belajar siswa dari siklus I, dimana skor aktivitas belajar siswa yaitu 9,00 berkategori cukup aktif, kemudian mengalami peningkatan pada siklus II yaitu 10,16 berkategori aktif. Selain itu, tes evaluasi belajar siswa dan presentase ketuntasan klasikal juga mengalami peningkatan, dimana dari siklus I menunjukkan rata-rata skor tes hasil belajar yaitu 74,81 dengan ketuntasan klasikal sebesar $81 \%$ (belum tuntas), kemudian pada siklus II dilakukan perbaikan-perbaikan pada siklus I sehingga terjadi peningkatan rata-rata skor tes hasil belajar yaitu 80,68 dengan ketuntasan klasikal sebesar $88 \%$ (tuntas). Dengan adanya peningkatan hasil belajar dan aktivitas belajar siswa dari siklus I ke siklus II, maka dapat disimpulkan bahwa penerapan model Numbered Heards Together dapat meningkatkan aktivitas dan hasil belajar pada pokok bahasan matriks siswa kelas XI IPS 2 SMAN 1 Wera tahun pelajaran 2019/2020.

Kata Kunci : Numbered Heards Together, Aktivitas Belajar, dan Hasil Belajar

\section{ABSTRACT}

The purpose of this study was to improve student activity and learning outcomes in the Matrix Class XI IPS 2 material at SMAN 1 Wera in the 2019/2020 Academic Year through the application of the Numbered Heards Together model. This type of research is Classroom Action Research. This research was conducted in two cycles which contained the stages of planning, implementation, observation and reflection. This research instrument uses; (1) Learning Implementation Plan (2) evaluation of learning outcomes tests given in each cycle of teaching and learning activities (3) observation sheets that are used to obtain a direct picture of the learning activities of teachers and students through the application of Source Heards Together.

From the results of the study it can be concluded that the application of the Number Heards Together model can improve student mathematics learning, this is indicated by the average score of student learning activities from cycle I, where the score of student learning activities is 9.00 categorized as quite active, then has an increase in the second cycle is 10.16 active categories. In addition, the student learning evaluation test and the percentage of classical completeness also increased, where from the first cycle showed an average score of learning outcomes test that was 74.81 with a classical completeness of $81 \%$ (incomplete), then in the second cycle improvements were made in the first cycle so that an increase in the average score of learning outcomes test is 80.68 with a classical completeness of $88 \%$ (complete). With an increase in student learning outcomes and learning activities from cycle I to cycle II, it can be concluded that the application of the Numbered Heards Together model can improve learning activities and outcomes on the subject matter matrix of class XI IPS 2 of SMAN 1 Wera in the academic year 2019/2020.

Keywords: Numbered Heards Together, Learning Activities, and Learning Outcomes 


\section{PENDAHULUAN}

\section{A. Latar Belakang}

Peran pendidikan sangat penting untuk menciptakan masyarakat yang cerdas, damai, terbuka, dan demokratis. Menurut Crow and Crow menyatakan bahwa pendidikan merupakan proses dimana pengalaman atau informasi diperoleh sebagai hasil dari belajar, oleh karena itu, pembaruan pendidikan harus selalu dilakukan untuk meningkatkan kualitas sumber daya manusia (Rifai dan Anni, 2009 : 190). Tempat untuk memperoleh pendidikan yang baik adalah sekolah. Sekolah sebagai suatu lembaga pendidikan formal menyediakan fasilitas bagi siswa untuk melakukan berbagai kegiatan belajar untuk memperoleh pengalaman pendidikan, Sehingga dapat mendorong pertumbuhan dan perkembangan siswa kearah tujuan dan citacitanya.

Berdasarkan data observasi dan wawancara langsung dengan guru pengampu mata pelajaran matematika kelas XI SMA N 1 Wera. Data yang didapat bahwa pada saat proses pembelajaran matematika masih cenderung pasif seperti kurangnya keinginan siswa untuk bertanya, Siswa kurang berminat dengan pembelajaran matematika karna tertuang dalam wacana yang relatif panjang dan banyak hitungannya, dan Metode pembelajaran sering di terapkan dalam pembelajaran matematika adalah metode ceramah, sehingga kurang melibatkan siswa secara langsung, hal ini dapat dilihat dari interaksi dan kebiasaan siswa dalam kelas.

\section{B. Rumusan Masalah}

Berdasarkan uraian maka dapat dirumuskan masalah dalam penelitian ini adalah Bagaiman Penerapan Model Pembelajaran Number Heards Together (NHT) dapat meningkatkan Aktivitas dan Hasil Belajar Pada Pokok Bahasan Matriks Siswa Kelas XI IPS 2 SMAN 1 Wera Tahun Pelajaran 2019/2020.

\section{TINJAUAN PUSTAKA}

\section{A. Pembelajaran Numbered Heads Together (NHT)}

Model pembelajaran merupakan pola yang digunakan sebagai pedoman dalam merencanakan pembelajaran di kelas, termasuk di dalamnya penyusunan kurikulum, mengatur materi, menentukan tujuan-tujuan pembelajaran, menentukan tahap-tahap dalam kegiatan pembelajaran, lingkungan pembelajaran, dan pengelolaan kelas. 
Isjoni (dalam Lestari, 2015: 20) menjelaskan bahwa pembelajaran kooperatif adalah pembelajaran yang menggunakan kelompok-kelompok kecil sehingga siswa-siswa saling bekerja sama untuk mencapai tujuan pembelajaran. Pembelajaran kooperatif juga mengkondisikan siswa untuk aktif dan saling member dukungan dalam kerja kelompok untuk menuntaskan materi masalah dalam belajar. Trianto (dalam Maryam, 2012: 23) menyebutkan dalam model pembelajaran kooperatif terdapat beberapa variasi atau tipe model yang dapat diterapkan, salah satu diantaranya adalah tipe NHT (Numbered Heads Together). NHT pertama kali dikembangkan oleh Spencer Kagen pada tahun 1993 untuk menelaah materi pelajaran dan mengecek pemahaman mereka terhadap isi pelajaran tersebut. NHT atau penomoran berpikir bersama merupakan tipe pembelajaran kooperatif yang dirancang untuk mempengaruhi pola interaksi siswa sebagai alternatif terhadap struktur kelas tradisional.

Suprijono (dalam Hapsari, 2017: 22) berpendapat bahwa model NHT (Numbered Heads Together) adalah model pembelajaran yang diawali dengan Numbering yaitu guru membagi kelompok dan tiap orang dalam tiap kelompok diberi nomor. Kemudian guru mengajukan beberapa pertanyaan dan pada kesempatan ini tiap kelompok menyatukan kepalanya "Heads Together" berdiskusi memikirkan jawabannya. Selanjutnya guru memanggil siswa yang memiliki nomor yang sama dari tiap kelompok dan mendiskusikan jawaban yang paling tepat.

NHT juga banyak sekali digunakan sebagai bahan penelitian tindakan kelas (PTK) karena NHT lebih mengedepankan kepada aktivitas siswa dalam mencari, mengolah, dan melaporkan informasi dari berbagai sumber yang akhirnya dipresentasikan di depan kelas sehingga dapat melatih siswa untuk saling berbagi informasi, mendengarkan dengan cermat serta berbicara dengan penuh perhitungan, sehingga siswa lebih produktif dalam pembelajaran. Terdapat empat langkah Penerapan Model Pembelajaran Kooperatif Tipe Numbered Heads Together Berbantuan Media Interaktif untuk Meningkatkan Aktivitas dan Prestasi Belajar Siswa (Agni Era Hapsari). yang dapat dilakukan dalam proses pembelajaran dengan teknik Numbered Heads Together adalah berikut ini:

\begin{tabular}{lll}
\hline No & Langkah-langkah & Aktivitas siswa \\
\hline 1 & $\begin{array}{l}\text { Penomoran } \\
\text { (Numbered) }\end{array}$ & $\begin{array}{l}\text { Guru membagi para siswa menjadi beberapa kelompok atau } \\
\text { tim yang beranggotakan 3-5 orang dan member nomor } \\
\text { sehingga tiap siswa dalam tim memiliki nomor yang berbeda }\end{array}$ \\
\hline 2 & $\begin{array}{l}\text { Pengajuan } \\
\text { Pertanyaan } \\
\text { (Questioning) }\end{array}$ & $\begin{array}{l}\text { Guru mengajukan pertanyaan kepada siswa dan pertanyaan } \\
\text { ini bervariasi mulai dari yang spesifik sampai ke hal-hal yang } \\
\text { bersifat umum }\end{array}$ \\
\hline 3 & Berfikir Bersama & Menggambarkan dan meyakinkanbahwa setiap anggota \\
\hline
\end{tabular}




\begin{tabular}{lll}
\hline & (Heads Together) & kelompok mengetahui jawaban tersebut \\
\hline 4 & $\begin{array}{l}\text { Pemberian Jawaban } \\
\text { (Answering) }\end{array}$ & $\begin{array}{l}\text { Guru menyebut satu nomor dan para siswa dari tiap kelompok } \\
\text { dengan Nomor yang sama mengangkat tangan dan } \\
\text { menyiapkan jawaban untuk seluruh kelas }\end{array}$ \\
\hline
\end{tabular}

Beberapa manfaat pada model pembelajaran kooperatif tipe NHT terhadap siswa yang hasil belajar rendah yang dikemukakan oleh Lundgren (dalam Kahasanah, 2013: 18), antara lain adalah: rasa harga diri menjadi lebih tinggi, memperbaiki kehadiran, penerimaan terhadap individu menjadi lebih besar, perilaku mengganggu menjadi lebih kecil, konflik antara pribadi berkurang, pemahaman yang lebihmendalam, meningkatkan kebaikan budi, kepekaan dan toleransi, hasil belajar lebih tinggi.

Sehingga berdasarkan pengertian di atas bahwa NHT adalah bagian dari model pembelajaran kooperatif struktural, yang menekankan pada struktur-struktur khusus yang dirancang untuk mempengaruhi pola interaksi siswa yang lebih mengedepankan kepada aktivitas siswa dalam mencari, mengolah, dan melaporkan informasi dari berbagai sumber yang akhirnya dipresentasikan di depan kelas sehingga dapat melatih siswa untuk saling berbagi informasi, mendengarkan dengan cermat serta berbicara dengan penuh perhitungan, sehingga siswa lebih produktif dalam pembelajaran.

\section{B. Aktivitas Belajar}

Anak yang belajar selalu melakukan aktivitas. Aktivitas siswa selama proses pembelajaran merupakan salah satu indikator adanya keinginan siswa untuk belajar. Reber (Syah, 2004: 109) mengemukakan bahwa aktivitas adalah proses yang berarti cara-cara atau langkah-langkah khusus yang dengan beberapa perubahan ditimbulkan hingga tercapainya hasil-hasil tertentu. Menurut Sardiman (dalam Hapsari, 2017: 24) aktivitas belajar merupakan prinsip atau azas yang sangat penting didalam interaksi belajar-mengajar. Aktivitas yang dimaksud disini bukan hanya aktivitas fisik tetapi mencakup aktivitas mental. Pada kegiatan belajar, kedua aktivitas tersebut saling berkait. Aktivitas fisik adalah peserta didik giat aktif dengan anggota badan, membuat sesuatu, beriman ataupun bekerja, ia tidak hanya duduk dan mendengarkan, melihat atau hanya pasif. Peserta didik yang mempunyai aktivitas psikis adalah jika daya jiwanya bekerja sebanyak-banyaknya dalam rangka pembelajaran. Seluruh peranan dan kemauan dikerahkan dan diarahkan supaya daya itu tetap aktif untuk mendapatkan hasil pengajaran yang optimal

\section{Hasil Belajar}


Nana Sudjana (dalam Lestari, 2015: 15) berpendapat belajar adalah suatu proses yang ditandai dengan adanya perubahan pada diri seseorang. Perubahan sebagai hasil dari proses belajar dapat ditunjukkan dalam berbagai bentuk seperti perubahan pengetahuan, sikap dan tingkah laku, keterampilan, kecakapan, kebiasaan serta perubahan aspek-aspek lain yang ada pada individu yang belajar.

Hasil belajar adalah suatu hasil usaha yang telah dicapai oleh siswa yang mengadakan suatu kegiatan belajar di sekolah dan usaha yang dapat menghasilkan perubahan pengetahuan, sikap dan tingkah laku. Hasil perubahan tersebut diwujudkan dengan nilai atau skor (Winkel, 2005: 532). Muhibin Syah (dalam Hapsari, 2017: 14) menjelaskan Hasil belajar adalah setiap macam kegiatan belajar menghasilkan suatu perubahan yang khas yaitu hasil belajar. Menurut Lukman Ali (dalam Lestari, 2015: 18) dikatakan bahwa Hasil belajar adalah hasil usaha yang telah dicapai atau yang telah dikerjakan untuk mendapatkan suatu kecakapan dan kepandaian.

Berdasarkan beberapa pendapat di atas, maka dalam penelitian ini yang dimaksud hasil belajar adalah suatu hasil usaha yang telah dicapai oleh siswa baik penguasaan pengetahuan atau keterampilan sebagai hasil belajar yang ditunjukkan dengan nilai atau angka yang diberikan oleh guru. Hasil dalam penelitian dimaksudkan adalah nilai yang diperoleh siswa pada mata pelajaran sejarah yang berupa angka yang diberikan oleh guru setelah melakukan tugas yang diberikan oleh guru kepada siswa.

\section{METODE PENELITIAN}

Penelitian ini dilaksanakan di SMAN 1 Wera pada semester ganjil Tahun Pelajaran 2019/2020. Subjek dalam penelitian ini adalah siswa kelas XI IPS 2 sebanyak 30 orang. Penelitian tindakan kelas ini dilaksanakan pada pokok bahasan matriks dengan dua siklus, dari masing-masing siklus, dilakukan 5 tahapan kegiatan yaitu perencanaan, pelaksanaan, observasi, evaluasi dan refleksi.

Data-data penelitian diambil dengan menggunakan instrumen penelitian yaitu lembar observasi aktivitas siswa yang terdapat 6 indikator yaitu kesiapan siswa dalam menerima pelajaran, aktivitas siswa dalam langkah penomoran, langkah pengajuan pertanyaan, langkah berpikir bersama, langkah pemberian jawaban, dan partisipasi siswa dalam menutup kegiatan pembelajaran. Lembar aktivitas guru terdapat 6 indikator yaitu kesiapan dalam pembelajaran, mengorganisasikan siswa untuk belajar (langkah penomoran), mengajukan pertanyaan /permasalahan, memberikan tugas kelompok (langkah berpikir bersama), memberikan 
kesempatan siswa untuk menjawab (langkah pemberian jawaban), menutup kegiatan pembelajaran.

Untuk menentukan kriteria aktivitas siswa digunakan skor standar seperti tertera pada tabel berikut ini :

\begin{tabular}{c|c|c}
\hline Interval & Interval Skor & Kriteria \\
\hline$X \geq M i+1,5 S D i$ & $X \geq 13,5$ & Sangat Aktif \\
\hline$M i+0,5 S D i \leq X<M i+1,5 S D i$ & $10,5 \leq X<13,5$ & Aktif \\
\hline$M i-0,5 S D i \leq X<M i+0,5 S D i$ & $7,5 \leq X<10,5$ & Cukup Aktif \\
\hline$M i-1,5 S D i \leq X<M i-0,5 S D i$ & $4,5 \leq X<7,5$ & Kurang Aktif \\
\hline$X<M i-1,5 S D i$ & $X<4,5$ & Sangat Kurang Aktif \\
\hline
\end{tabular}

Sumber : Nurkancana, (dalam Juliana, 2019: 83)

\section{HASIL DAN PEMBAHASAN}

Penelitian tindakan kelas ini dilakukan sebagai upaya untuk meningkatkan aktivitas belajar siswa kelas XI IPS 2 SMAN 1 Wera Tahun Pelajaran 2019/2020 pada materi matriks dengan menerapkan model kooperatif tipe NHT (Numbered Heads Together). Ringkasan hasil penelitian dapat dilihat pada tabel dibawah ini.

\begin{tabular}{cccccccc}
\hline & Pert. & \multicolumn{2}{c}{ Aktivitas Guru } & \multicolumn{4}{c}{ Aktivitas belajar siswa } \\
\cline { 3 - 7 } & & Skor & Kategori & Skor & Kategori & Rata-rata skor & Kategori \\
\hline I & I & 16 & Sangat Baik & 8,33 & Cukup Aktif & \multirow{2}{*}{9,00} & \multirow{2}{*}{ Cukup Aktif } \\
& II & 16 & Sangat Baik & 9,67 & Cukup Aktif & \multirow{2}{*}{ Aktif } \\
\hline II & I & 17 & Sangat Baik & 8,66 & Cukup Aktif & \multirow{2}{*}{10,16} & \\
& II & 17 & Sangat Baik & 11,66 & Aktif & & \\
\hline
\end{tabular}

Dari tabel 2, hasil observasi aktivitas belajar siswa pada siklus I menunjukkan rata-rata skor sebesar 9,00 berkategori cukup aktif. Pada tahap siklus I pertemuan 1 aktivitas siswa dalam langkah penomoran, pengajuan pertanyaan, berpikir bersama, pemberian jawaban dan partisipasi siswa dalam kegiatan penutup cukup aktif. Kemudian pada pertemuan 2 siklus I terjadi peningkatan pada aktivitas siswa dalam langkah penomoran, berpikir bersama, pemberian jawaban dan dalam kegiatan penutup. Walaupun terjadi peningkatan skor aktivitas belajar siswa pada pertemuan 2 namun terdapat kekurangan-kekurangan yang masih dilakukan yaitu pada langkah penomoran, siswa masih membuat keributan saat pembagian kelompok, siswa masih belum bisa duduk dengan tertib bersama anggota kelompoknya, pada langkah pengajuan pertanyaan, siswa masih belum memahami pertanyaan yang termuat dalam LKS, pada langkah berpikir bersama, masih terdapat satu atau dua siswa yang menyelesaikan LKS, dan pada langkah pemberian jawaban kurang dari 50\% dari siswa 
menanggapi kelompok yang presentasi dan kurang dari 50\% dari siswa yang bertanya kepada kelompok yang presentasi. Aktivitas belajar siswa pada siklus I belum memenuhi indikator keberhasilan yang telah ditetapkan yaitu aktivitas belajar siswa minimal berkategori aktif.

Berdasarkan kekurangan-kekurangan yang terjadi pada siklus I, maka guru melakukan perbaikan pada siklus II. Adapun tindakan perbaikan yang dilakukan antara lain guru merombak kelompok dan memberikan teguran keras kepada kelompok yang masih membuat keributan agar proses pembelajaran berjalan efektif. Pada saat pelajaran pasti ada gangguan. Hal ini perlu guru sadari dan jangan dibiarkan. Teguran perlu dilakukan oleh guru untuk mengembalikan keadaan kelas. Teguran guru merupakan tanda bahwa guru ada bersama siswa.

Sebelum kegiatan diskusi dimulai, guru mengarahkan masing-masing kelompok untuk mengerjakan LKS bersama dengan seluruh anggota kelompok dan membagi tugas dengan baik. Kemudian guru memberikan kewajiban kepada setiap masing-masing kelompok untuk memberikan tanggapan dan pertanyaan terhadap hasil diskusi kelompok, guru memberikan arahan dan pertanyaan-pertanyaan yang memancing siswa untuk membuat kesimpulan, guru memberikan hadiah berupa poin tambahan kepada siswa yang berani membuat kesimpulan akhir kegiatan pembelajaran, guru mengingatkan batasan waktu untuk pengerjaan LKS agar sesuai dengan alokasi waktu yang ditetapkan. guru perlu memberikan penekanan (focusing) berupa peringatan akan aspek-aspek yang dirasa penting untuk memfokuskan perhatian siswa. Penekanan yang dimaksud disini adalah mengenai alokasi waktu yang tersedia pada setiap kegiatan, agar siswa dapat menyelesaikan tugasnya tepat waktu sesuai rencana yang telah dibuat oleh guru pada RPP.Guru juga mengingatkan siswa untuk membawa kelengkapan belajar untuk pertemuan berikutnya.

Selanjutnya setelah perbaikan tersebut diterapkan pada siklus II diperoleh hasil seperti siswa tidak membuat keributan saat pembagian kelompok, siswa duduk dengan tertib bersama anggota kelompoknya, siswa tidak mengerjakan pekerjaan lain saat kelompok sudah dibagikan, siswa membaca pertanyaan yang dimuat dalam LKS, siswa memahami pertanyaan, siswa mengetahui cara menyelesaikan soal dalam LKS, siswa membagi tugas dalam kelompok, siswa bekerjasama menyelesaikan soal yang diberikan, siswa memastikan semua anggota kelompok memahami jawaban kelompok, siswa menyampaikan jawaban hasil diskusi kelompok, siswa dengan nomor yang sama menanggapi jawaban yang telah disampaikan, siswa mengajukan pertanyaan kepada siswa yang pertama ditunjuk oleh guru, 
dan siswa memperbaiki atau menambahkan kesimpulan teman yang kurang tepat dan siswa mencatat kesimpulan dan tugas rumah yang diberikan.

Hasil yang diperoleh pada siklus II yang terlihat pada tabel 2 menunjukkan rata-rata skor aktivitas belajar siswa sebesar 10,16 berkategori aktif. Secara simultan terjadi peningkatan aktivitas belajar siswa. Dengan kata lain, aktivitas belajar siswa pada siklus II telah mencapai indikator keberhasilan. Berdasarkan data-data yang ada dapat digunakan untuk mengambil kesimpulan, untuk itu penelitian ini dihentikan.

Pada kegiatan pembelajaran kooperatif tipe NHT menekankan pada kegiatan belajar secara berkelompok dengan masing-masing siswa diberi tanggung jawab untuk menyelesaikan soal atau permasalahn sesui nomor yang telah ditetapkan oleh guru. Pada fase tanya jawab (Questioning) guru menunjuk kelompok dengan nomor kepala tertentu. Pada fase merancang dan melakukan percobaan guru membimbing siswa melakukan percobaan untuk mendapatkan data dan kemudian siswa menganalisis data mengevaluasi data hasil percobaan. Untuk kegiatan yang terakhir guru bersama siswa membuat kesimpulan dari pembelajaran yang dilakukan. Dari langkah-langkah pembelajaran tersebut, siswa akan bisa mengikuti pelajaran dengan baik dan menyenangkan. Dalam penelitian menyatakan bahwa aktivitas belajar siswa terhadap pembelajaran dengan model kooperatif tipe NHT diukur menggunakan lembar observasi. Adapun aktivitas yang siswa yang dilakukan yaitu: Visual activities; Oral activities yang meliputi bertanya kepada guru, bertanya kepada teman, mengeluarkan pendapat; Writing activities; dan Mental activities.

Aspek-aspek yang diobservasi untuk aktivitas siswa yaitu; 1) membalas salam guru dan do'a bersama, (2) mempersiapkan diri untuk mengikuti pembelajaran, (3) memperhatikan penjelasan guru, (4) menjawab pertanyaan yang diajukan, (5) memperhatikan materi yang dijelaskan oleh guru, (6) siswa duduk bersama kelompok dan sesuai nomor yang telah ditentukan, (7) mengerjakan LKS secara berkelompokdan berpikir bersama untuk meyakinkan agar semua anggota kelompok tahu jawabannya, (8) bertanya kepada guru jika mengalami kesulitan dalam mengerjakan LKS, (9) siswa yang disebutkan nomornya mempresentasikan hasil kerja kelompok, (10) menyimpulkan jawaban akhir dari setiap pertanyaan dalam kegiatan diskusi kelas, (11) mengerjakan soal tes akhir tindakan.

Dengan demikian, berdasarkan pembahasan di atas maka penerapan model kooperatif tipe Numbered Heads Together pada Pokok Bahasan Materi Matriks dapat meningkatkan aktivitas dan hasil belajar siswa kelas IPS 2 SMAN 1 Wera tahun pelajaran 2019/2020. 


\section{KESIMPULAN}

Dari hasil penelitian dapat disimpulkan bahwa Aktivitas belajar siswa kelas IPS 2 SMAN 1 Wera Tahun Pelajaran 2019/2020 pada pembelajaran materi matriks dapat meningkat dengan menerapkan model kooperatif tipe Numbered Heads Together. Peningkatan ini dapat dilihat dari rata-rata skor aktivitas belajar siswa berkategori kurang aktif sebelum menerapkan model Numbered Heads Together menjadi berkategori aktif pada akhir siklus.

Adapun saran-saran yang dapat disampaikan oleh peneliti dari hasil penelitian ini sebagai berikut.

1. Bagi guru matematika dapat menerapkan model kooperatif tipe Numbered Heads Together sebagai alternatif pembelajaran di kelas sehingga akan menambah pengalaman baru untuk memudahkan siswa dalam menerima pelajaran sebagai upaya untuk meningkatkan aktivitas belajar siswa.

2. Bagi siswa diharapkan dapat lebih aktif dan termotivasi untuk membangun pemahaman konsepnya secara mandiri melalui kerjasama kelompok.

3. Bagi peneliti selanjutnya yang menerapkan Model Kooperatif Tipe Numbered Heads Together agar lebih memperhatikan langkah-langkah kegiatan pembelajaran yang dapat memacu siswa sehingga mendapatkan hasil yang lebih baik.

\section{DAFTAR PUSTAKA}

Hapsari, AE. 2017. Penerapan Model Pembelajaran Kooperatif Tipe Number Heads Together (NHT) Untuk Meningkatkan Aktivitas dan Hasil Belajar Siswa. Jurnal Scholaria diterbitkan

Lestari, CS. 2015. Penerapan Metode Pembelajaran Number Heads Together Untuk Meningkatkan Hasil Belajar Siswa Kelas X TPHP di SMK N I Pandak. Universitas Negeri Yogyakarta.

Maryam, St. 2012. Penerapan Model Pembelajaran Number Heads Together untuk Meningkatkan Hasil Belajar Matematika Siswa Kelas V SDN 1 Pinrang. Jurnal Publikasi Pendidikan atau Article Matrics.

Khasanah, D. 2013. Keefektifan Model Pembelajaran Kooperatif Tipe Talking Stick: Universitas Negeri Semarang.

Mulia, DS. 2016. Penelitian Tindakan Kelas dengan Pembelajaran Kearifan Lokal. Jurnal Ilmiah Khazanah Pendidikan. 
Solihatin, E,dan Raharjo. 2008. Cooperatif Learning Analisis Model Pembelajaran IPS, Jakarta: Bumi Aksara.

Sulfiani, R. 2016. Penerapan Model Pembelajaran Cooperatif Learning Tipe Number Heads Together untuk Meningkatkan hasil belajar Kimia Siswi Kelas XI IPA I SMAN 3 Watampone, Jurnal Chemica.

TIM Penyusun KBBI. 2003. Kamus Besar Bahasa Indonesia. Jakarta : Balai Pustaka

Wiriatmadja, R. 2007. Metode Penelitian Tindakan Kelas Untuk Meningkatkan Kinerja Guru dan Dosen, Bandung: PT. Remaja Rosda Karya. 